\title{
Gender Dynamics in Agro-biodiversity Conservation in Sikkim and Nagaland*
}

\author{
Chanda Gurung GoOdrich
}

\section{Introduction}

Subsistence farmers all over the world, and especially in environments where high-yielding crops and livestock do not prosper, play a major role in maintaining agro-biodiversity by cultivating a large variety of crop species. The Convention on Biodiversity defines agro-biodiversity as 'the diversity at all levels of the biological hierarchy, from genes to ecosystems, that is involved in agriculture and food production ... . the fundamental and distinct property of agricultural biodiversity is that it is largely created, maintained and managed by humans' (Secretariat of the Convention on Biological Diversity 2001). Thus, agro-biodiversity is the biological diversity of agriculture-related species and their wild varieties which occurs at the levels of the agro-ecosystem, species and gene. Today, agro-biodiversity is being seriously depleted due to genetic erosion, which is one of the most alarming threats to world food security. It is known that 75 per cent of the world's food is generated from just 12 plant and five animal species. Only 200 out of 10,000 edible plant species are used by humans, and of these, rice, maize and wheat contribute nearly 60 per cent of the calories and proteins obtained by humans from plants (Lambrou and Laub 2006). The importance of biodiversity and plant genetic resources in human survival and food security makes it vital to maintain crop diversity on farmers' fields, especially in 'hot spots' of plant genetic diversity. Indeed, this is considered a 'global life insurance policy' by the Convention on Biology Diversity (Secretariat of the Convention on Biological Diversity 2001). In such a scenario, the contribution of the farmers of the eastern Himalaya and the northeastern hills in 
conserving and maintaining agro-biodiversity is of immense value. Conservation practices in the region are traditionally adaptive strategies based on indigenous knowledge. This essay draws upon research conducted in three sites - in Sikkim and Nagaland in India and Sankhuwasabha in Nepal - to understand the causal links between ethnicity and gender, and how these affect agrobiodiversity management practices. The essay, however, focuses on the research findings from Nagaland and Sikkim concerning how social and agricultural practices in some of the indigenous ethnic communities of this region have evolved to conserve and maintain crop diversity, and examines the criticality of gender for agro-biodiversity conservation.

\section{Social and Gender Systems and Livelihood Practices}

Humans have lived in this region for several millennia, adapting their custom, lifestyles and livelihoods to the local environments. Historically, the region and its people have been exposed to various external influences - transhumance of people due to war and conquest, trade, out-migration, and immigration. More contemporarily, development interventions have considerably broadened the range and nature of encounters. As a consequence, the cultural discourse of the region's societies has evolved through a process of mediation, negotiation and resistance to external influences (Gurung 1999). All this movement and inter-mixing of communities in the rugged terrain is reflected by the diversity of ethnic and religious groups across the region. Their survival depends on subsistence farming and necessitates the extensive use and management of natural resources. Besides producing many types of crops (mostly landraces), farmers rely extensively on wild plants to meet their needs for fiber, shelter, food, medicine, tools, and household implements.

Among the numerous ethnic communities of this region are the Lepchas of Sikkim and the Nagas of Nagaland. For the last halfcentury, like other ethnic groups that inhabit the middle mountain ranges, these communities too have been exposed to a myriad influences. The Lepchas have been exposed to the Lamaist culture of Tibetan-Buddhism, the caste system of Hinduism brought by the Nepalis, and the greater 'egalitarianism' of Christianity. 
Similarly, the Nagas have been exposed to the British, the Christian doctrines brought by the British and American missionaries and to the low-landers of India. The process of interaction with and influence of these external hegemonies was based on relations of inequity. Stratification on the basis of class, caste, wealth, religion, and gender became the norm. Prior to this, the divisions and/ or stratifications were based on clan and tribe affiliation rather than these parameters. In such a context, the external and more powerful groups came to be ranked higher in status, while the ethnic communities became 'second-class' citizens in their own land. Such encounters led to Hindu and Christian gender ideologies that follow patriarchal practices having a major influence over the communities' way of life. This had a strong impact on the ways gendered spaces and gender relations came to be conceptualised in the culture and practice of these ethnic groups. Adding to such historically embedded asymmetries are the present centre/periphery relations and lowland/highland dichotomies. All these have led to transforming the sustainable lifestyles of the people, their socio-cultural values and systems as well as subsistence practices.

The traditional subsistence systems and livelihood practices of the Lepchas and the Nagas were hunting-gathering, considered 'men's domain', and slash and burn cultivation, considered 'women's domain'. This gender division of labour and spaces was based on the cultural belief derived from biological attributes that women were the symbols of fertility, 'caretakers and nurturers', and men the 'active providers'. This was more a matter of convenience and physical endurance than power and control. However, due to the external encounters and hegemonies, the traditional livelihood practices have undergone transformation as private property tenure was introduced leading to settled agricultural practices, which gradually began to replace traditional subsistence systems of hunting-gathering and slash and burn cultivation. Traditional social and gender systems too underwent changes because social and gender systems of a community, although linked to religion and ethnic identities, are also strongly influenced by external forces (Gurung and Gurung 2006). As these traditional societies faced new influences and practices, the social, and more particularly, gender relations were reinterpreted and renegotiated (Gurung 1999). With the transformation in livelihood practices - which included not only new technologies and 
crops but also new beliefs and value systems that were attached to these activities - traditional gendered spaces in the livelihood systems too underwent transformation: agricultural space gradually came under the control and domain of men. Farming systems and what goes on within them came to be seen as 'the work place', where production for the market occurs; it is a domain or area that is spatially and socially distinct from 'the home', therefore a 'public' domain. This 'public' world of work and production tended to be seen, and ideologically constructed, as the world of men (Zwarteveen 2008). Thus, women lost their control over this sphere of activity and came to be considered merely as 'helpers'. However, their workload in this sphere of activity in no way decreased.

Today, agriculture is the mainstay of the region and 70 per cent of the people depend on it. The climate and seasons are conducive for growing a large number of crops - cereals, fruits and vegetables - and the region's geographical characteristics allow farmers to cultivate subtropical and sub-temperate crops simultaneously and in the same location with comparative ease. Most of the famers cultivate crops under natural conditions with no external inputs such as chemical fertilisers.

Even today, two land-use types are extremely important for these communities: forests and agriculture. Despite the degradation and loss of two-thirds of the eastern Himalayan forests due to indiscriminate felling of trees over the last few decades, the forests harbour over 9,000 species of flora and fauna (Myers 1988) and are still of great significance to the people. For the peoples of these communities, the forests are not only sources of timber, fuel wood, other non-timber forest products (NTFPs), such as medicinal herbs, edible fruits and plants, but are also the sites for grazing, foraging and slash and burn cultivation. Within the agro-forestry system, agriculture combined with livestock provides the main subsistence for the majority as hunting was abandoned years ago. Land holdings are highly differentiated but marginal and small holdings form the bulk of the total.

\section{Gender and Agro-biodiversity Conservation}

As with most of the ethnic communities inhabiting the eastern Himalaya and the northeastern hills, for the Lepchas and Nagas 
too the conservation of agro-biodiversity developed as a strategy for survival and is not seen by the people themselves as conservation per se. The roles and responsibilities of men and women in conserving agro-ecosystems, species and genes are defined on the basis of the different skills and knowledge that they have acquired and the socio-cultural norms and practices that have shaped them. Furthermore, dominant and accepted cultural symbolism informed by a powerful spatial imagery carries strongly gendered ideological connotations that men should be the 'providers' whereas women should be nurturers and caretakers. Added to this are the ideologies and notions of women as symbols of fertility, the impurity of women, etc. Consequently, men and women are associated with different crops and spaces/domains. Thus, distinct gender roles in agricultural labour and spatial divisions in gendered domains of authority between the different agroecosystems and crops mean that women and men have unique relationships to agro-biodiversity (see also Oakley and Momsen 2005). The work done and knowledge held by men and women are also valued differently based on the social and gender systems of the communities.

\section{Agro-ecosystem Maintenance}

Traditionally, the Lepchas and Nagas practised only one type of land-use - slash and burn cultivation - where they cultivated all their crops: the Lepchas cultivated upland rice, millet, buckwheat and maize; the Nagas cultivated upland rice, job's tears (Coix lacryma-jobi), millet and maize. Women were in complete control of this type of cultivation and they did almost all the work, with men helping them only in the felling of trees and cutting or lopping bigger branches.

However, with external influences, new technologies in agriculture were introduced in the early 19th century, the most significant being terracing. Thus, several types of land-use were practised: swidden cultivation along with home gardens and wet terrace fields, and, in the case of the Lepchas, agro-forestry areas where the cash crop cardamom was extensively cultivated. These agro-ecosystems came to be divided and classified into 'male' and 'female' domains on the basis of the social and gender systems that had come to be dominant. Each of these agro-ecosystems came under the control of either men or women based on reasons 
pertaining to power, importance, value - both in terms of cash and prestige or status in the given social and gender system.

Among both the Lepchas and Nagas the wet terrace fields are prized possessions of the families for their fertile soils and proximity to water sources and they are usually reserved for wetland paddy. These are classified as a 'male domain' because wet rice is considered a major crop and additionally the area is usually large as compared to the other agro-ecosystems. Although women provide the bulk of the work here in sowing, transplanting, weeding, harvesting, and seed selection, their contribution is not established and they are considered merely as 'helpers'.

Lepchas have two types of terraces: a) the ari/yong irrigated terraces are located in the lower elevations and marshy areas. Crops grown here include wet land paddy (15 varieties), maize (six varieties), potato (four varieties), wheat (two varieties), pulses (four varieties) and soybean. b) rain-fed sukha bari where upland rice (three varieties), maize, buckwheat (two varieties), barley (four varieties), millet (four varieties) including kaguni/kamdak (in Nepali/Lepcha), sorghum, mustard (two varieties), and numerous tuber crops are cultivated.

Nagas (Angami tribe) have various types of terraces: i) Dsuzo rain-fed terraces, ii) dzutsu irrigated terraces, iii) waluli partially irrigated terraces near homesteads, iv) dzutse terraces near streams, which are irrigated throughout the year, v) khuso terraces located far away from the homestead and water sources, and vi) wakhra dry terraces located near the dzutse and khuso, where approximately 50 varieties of paddy are cultivated. Apart from this, other crops like maize (seven varieties), several varieties of millet and potatoes are also grown here.

Among both the communities home gardens (called leeden sing by the Lepchas) are considered part of the 'female domain' because these are usually small in size and the crops grown are all subsistence or 'minor' crops like vegetables, herbs and traditional crops only for home consumption. This agro-ecosystem has the highest diversity of crop species and varieties. Being 'caretakers' and 'nurturers', women are responsible for feeding their families and caring for their health. Therefore, they cultivate a variety of crops, vegetables and medicinal plants in the home gardens for family consumption and use. For instance, Lepcha women cultivate 24 vegetables (and many more varieties), seven types of 
spices and eight types of fruit crops in their home gardens; Naga women grow 30-40 varieties of beans, 30 varieties of squash, two varieties of mustard leaves, two varieties of cabbage, three varieties of garlic, two species and two varieties of tomatoes, three varieties of solanum, and several other vegetables like carrot, mint, spring onion, etc.

To optimise diversity with maximum yield, women of both communities try to utilise land as much, and in as many ways, as possible. As most of the farmers have small landholdings, women practise various crop combinations and crop rotation methods. Home gardens are also the area where women experiment with new crop species and varieties that they get from their different seed networks and also from the forests. Home gardens not only maintain but also sustainably improve crop diversity, thus making these extremely significant areas for the use and conservation of agro-biodiversity. The women carry out all the work in this area with the men rarely helping.

Slash and burn has been classified differently by the two communities: the Lepchas consider the sadlium area a 'joint domain' of men and women, while the Nagas consider jhum as a female farming system and thus a 'female domain'. The difference is largely based on the extent and type of interaction with and the policy adopted by the influencing or ruling powers. The history of the Lepchas shows that they were exposed to both the TibetanBuddhist and the Hindu-Nepali cultures over a long period. The Tibetan-Buddhist influence lasted longer as the ruling power, but was concentrated only in the cultural and religious sphere. The Hindu-Nepalis came to Sikkim to make a living; they were not rulers and mixed freely with the Lepchas. The close interaction between the two groups led to the Lepchas adopting a combination of the livelihood practices and values. The sadlium agro-ecosystem, which was completely under the control of women, is now considered a 'joint domain' of both men and women because work in this area is considered 'outside' work, within the men's sphere, but the crops cultivated here are minor crops which are associated with women. Hence, this is regarded as a joint domain.

Among the Nagas, the influence of and interaction with the Christian missionaries was concentrated only on the religious sphere while the influence of the lowlands is fairly recent. Therefore, the impact of both has not been felt so much in the livelihood 
systems and practices. Furthermore, the British policy of nonintervention in internal and personal matters, which allowed the Nagas to follow their own traditional customary laws and practices, is another reason for the traditional gender spaces/spheres of control being still relatively strong. Therefore, jhum cultivation is still very much a woman's farming system and the swidden plots are exclusively 'women's domain'. Women cultivate a mix of about 70 crops that include 34 varieties of upland rice, seven varieties of maize, and four varieties of job's tears, several varieties of millet, taro, ginger, chilies and cotton. Thus, there is an intimate link between jhum cultivation and crop biodiversity (Nakro and Kikhi 2006).

Despite the different ways in which slash and burn areas are viewed and categorised, the work done by women and men in this agro-ecosystem is almost equal and similar. Men do the 'heavy' work (this categorisation of 'heavy' and 'light' work is again based on the conventional gender ideology) of cutting trees and branches, while women clear the undergrowth; burning is done by both depending on whoever is free; sowing and weeding are done mostly by women, although the Lepcha men do help sometimes, but among the Nagas, this work is done solely by the women; harvesting is done by both women and men.

The punzok agro-forestry area is unique to the Lepchas. These are areas within the forest which are considered a male domain and an extension of the forest where traditionally men hunted game. In addition, six varieties of cardamom, a major cash crop and so under men's control, is cultivated here. Women have no control over this area. Men do all the work of planting, weeding, pruning, harvesting, curing, and marketing. Women are rarely involved and only serve as helpers when there is a shortage of male labour.

\section{SpeCies Conservation}

Formerly, the Lepchas and Nagas cultivated only the traditional crop species of which there were numerous varieties. All the crops were of equal value and importance. External influences, the introduction of new crops and new forms of patriarchy, have altered farming practices and gender relations. The most significant of these new crops is wetland rice. The irrigated rice and wheat became major crops and were associated with men. With 
other traditional crops beginning to lose their use value, specific crops came to be seen as men's crops or women's crops on the basis of their economic importance, food value and cultural significance. Men were more involved with the production of major crops (rice, millet, maize and cardamom) and women with minor subsistence crops and vegetables. Crop varieties also declined as farmers preferred exotic seeds and high-yielding hybrids.

As traditional crops lost their importance, a higher value was given to fruits and cash crops which are important to the cash economy. All these changes occurred with the introduction and development of new and improved seed varieties without community control and by ignoring the empowerment of mountain farmers and their ability and freedom to choose in the context of local knowledge. These introduced crops affected the agro-biodiversity and the consequences were alarming in the long term. The Lepchas who used to cultivate 27 varieties of dry rice (Gorer 1938) and 12 varieties of millet (Siiger 1967), now cultivate only two varieties of dry or upland rice (that too only in the remote areas), and four varieties of millet. Of several traditional crops, only millet is considered a major crop now because of its cultural and religious value and because its use in the making of the traditional brew, beer, is a pre-requisite in all religious and cultural functions; it is also the main offering to the gods and to guests. Similarly, the Nagas traditionally used to cultivate 30 varieties of millet and job's tears but the number of varieties of these crops has been decreasing gradually, while the number of irrigated paddy varieties is increasing. Now there are approximately 30 varieties of wet rice being cultivated even in the one small village, Viswema, which was one of the research sites of the study.

Thus, at the species level, the major crops, which are associated with and are under the control of men, have far fewer varieties. On the other hand, the traditional and subsistence crops that are now considered minor crops, and associated with and cultivated by women, have a huge diversity of species and varieties. Unfortunately, the way gender relations operate today, women benefit very little from their major role in the conservation of agrobiodiversity. This despite the fact that women are doing most of the work in the cultivation of the 'major' crops also as they are involved in all the stages of work (sowing, transplanting, weeding, manuring, harvesting, storage, seed selection, seed keeping and also seed exchange to some extent). 


\section{Genetic Management}

The linkage between agro-biodiversity and distinct gender roles is particularly in relation to seed management which involves seed selection, seed saving and seed exchange (Howard 2003; HowardBorjas 2001; Momsen 2004; Rocheleau et al. 1996; Sachs et al. 1997; Zimmerer 1996). Traditionally, as well as in the present context, this sphere falls under the 'women's domain' among both the Nagas and the Lepchas. Thus, this is the only sphere where there has been no change in the gender roles and authority. Women select and store seed of all crops, major and minor, except cardamom, the Lepchas' cash crop. The older women in particular do this work because of their experience and because the tasks require less physical effort. Such a role is legitimised by culture and gender ideology as women are considered the symbols of fertility. The women have exclusive control of decision-making processes and the practice of seed management. Thus, women are the knowledge holders of genetic management at the household level, which is crucial not only for conserving agro-biodiversity but also for their livelihood. This knowledge is obtained from first-hand experience beginning at a very young age. Information is passed down and learnt from female relatives through observation, demonstration and participation.

Seed management systems involve selection, storage and supply/exchange. Seed selection is done on the basis of several morphological criteria such as health, freedom from disease, drought resistance, resistance to wind and rain, and grain quality. Besides, women also have certain preferences. For instance, they select for early ripening, palatability, ease in grinding, preparation and processing time, and suitability for fodder, etc. It was found that they rarely look for market value. Women also have various traditional and indigenous methods of saving and storing seeds.

The major source of seeds for most farmers among both the Lepchas and the Nagas is their own household, which accounts for approximately 90 per cent of the seed supply. In addition, there are elaborate terms of exchange between family members, neighbours and neighbouring villagers. Within villages, exchange is an important means by which seed quality is retained within communities. Women are the decision-makers and are directly involved in the exchange of seeds within the village, sharing views and information on how the seed is selected and stored, 
and what varieties and seed qualities others have. In this way, they serve as seed conservers. Seed swapping within a village is occasionally done by men under the guidance of women. Visiting female relatives, especially married daughters, always carry seeds to and from their husbands' villages. During such visits women also exchange views and information regarding seed selection and storage.

Box 7.1: Example from the Chekasang Tribe of Nagas

Among the Chekasang Nagas, it was not uncommon for a daughter married and living in another village to carry seeds when visiting her natal home. Traditionally, in times of war between tribes, the daughters were known to carry seeds hidden in the goiter of chickens. Also, it was not unusual for some girls to be sent off in marriage to enemy tribes to learn the secrets of seed management. While preparing to come home, such women are known to have fed the choicest grains to chickens that they would carry with them and which would then be slain in their natal village. New seed sources were maintained in this way.

Source:Field notes.

Seeds purchased from the market are considered 'external' because men as 'providers' conduct 'outside' work where women have no control over these sources.

Thus, women's distinct social networks and their higher dependence on these networks (Agarwal 2000) are a backbone to agrobiodiversity conservation. Women have played and continue to play a key role as indigenous breeders, knowledge managers and seed distributers (Inhetveen 1998). As women have a better understanding of how seed exchange networks are maintained, genetic losses are avoided through years of learning and oral tradition.

Although there has been no change in the gender role and authority in the gendered space of agro-biodiversity, there has been a drastic change as regards the valuation and importance of the work and knowledge held. Previously, this work and knowledge was given its due importance, but once agriculture became the domain of men and women lost control over it, and the market economy also came to be dominant, women's work as well as knowledge of genetic resource management was undervalued. 
Neither men nor women give importance to such a vital task. Both men and women view women's work with seed management as a socially constructed role of convenience: women work near the home whereas men are in the fields, and seed management is considered to be a home-based activity (Oakley and Momsen 2005). In the words of the Lepcha women it is 'basi biyalo garne kaam' meaning work that is to be done at leisure. Indeed, women's contributions to agro-biodiversity management (seed selection and storage, pruning and tending plants, etc.) are not considered activities in their own right, but rather an extension of women's reproductive chores (Padmanabhan 2005). Thus, seed management work and knowledge is in the 'women's sphere' and considered 'inside' work, not of much importance in the context of gender relations in the contemporary cash economy.

However, it is also not unusual for men to become involved in seed selection and saving activities, especially when physical disabilities hamper them from doing other heavy agricultural tasks. Interestingly, their knowledge is passed to their daughters and not sons, thus such role change is temporary, based on the current practical needs of the family. When due to whatever circumstances a man takes over seed work, the value and importance immediately increases and his status in the society too rises. This is very clear in a case where a man belonging to the Lepcha community had taken up this work as he was physically too weak to carry out other 'heavy' work ascribed to men. He had acquired the knowledge of seed selection and storage from his mother and wife. His role as a man gave him wider mobility whereby he could go out and get new varieties and also more information. Besides, as a man he was free of the daily household and reproductive chores, thus giving him the time to experiment in the fields with new crop varieties. As a result he had introduced several new varieties of maize, rice and vegetables in his village. Thus, he acquired the position of a seed expert not only in this village but also in the neighboring villages, gaining him immense prestige and status. The case distinctly shows that what is actually an intellectual and manual task becomes invisible when done by women, as then transactions take place away from the market in the realm of another reproductive task and so are considered as an extension of 'women's nature'. Whereas when this same task is performed by a man and takes place in the realm of the cash 
economy then additional value is added to it. As pointed out by Padmanabhan (2005) the misconceptualisation of women's work as their essential character and not as part of their labour is still a powerful tool to dilute women's contributions and respective claims.

\section{Food Habits, Food Preferences and Preparation Methods}

Another extremely important factor that contributes to the conservation of crop species and varieties is that of its utilisation. The specific crop species and varieties are conserved through their utilisation, which is ultimately linked to a lifestyle (Padmanabhan 2005) including food habits and food preferences. With the introduction of new crops, especially white rice cultivated in wet terraces, and the external influences that have transformed social and gender systems, food habits, preferences and preparation methods too have changed having a direct impact on how agrobiodiversity is maintained and conserved. Thus, crop diversity is inextricably linked to the numerous food habits of the ethnic groups. Because women have to take care of food preferences and preparation, they possess extensive knowledge of the particular characteristics of different varieties of 'minor' and subsistence crops. Men too possess such knowledge but with regard to the major crops and other cash crops.

Women continually experiment and try out new varieties with the preferred traits in their 'domains' so that they can have more options. For instance, Naga women first try out new varieties in small plots near the field hut where they can observe their growth regularly, and if this meets all the characteristics they require to fulfil the food habits, the variety is accepted and cultivated in their home gardens and swidden fields.

\section{Conclusion}

Past events in the eastern Himalaya and the northeastern region and the human populations of neighbouring states and countries had an enormous impact on the gender relations of the communities whereby 'providers' (men) have become more dominant than 'caretakers' (women). Now, the dynamics and complexities of gender-segregated power relations within households and 


\section{Box 7.2: Some Examples}

White rice grown in wet terraces is now the most important crop in terms of taste as well as social prestige. There are numerous ways of preparing rice - Lepchas do this in five different ways and the Nagas have seven ways. The number of varieties cultivated is also the highest as compared to other cereal crops like maize, wheat, millet, upland rice, etc.

Due to the significance of wetland rice, ghaiya, the traditional upland rice has gradually lost its importance, especially among the Lepchas, leading to a drastic decrease in the varieties cultivated. However, among the Nagas, this crop is still an important food and they have many ways of preparation, so even today 34 varieties of upland rice are cultivated.

Maize is an important crop especially as it is an alternate source of food during scarce periods. It is prepared in numerous ways. However, since this crop is not considered of social and cultural value, but only for 'filling the stomach', the number of varieties is the same as that of wetland rice.

Millet, a traditionally important crop has lost much of its food value. It is still of religious and cultural importance to the Lepchas. However, as they use this crop only for religious rituals and social ceremonies in the form of chi (a fermented alcoholic brew) the number of varieties of millet has decreased drastically.

Among the Nagas, job's tears is a traditionally important crop associated with feasts of merit (offered to the ritual specialist who conducts the rituals related to all agricultural activities, along with rice and meat) but has lost its importance, as feasts of merit are rarely, if ever, given and the crop is also not eaten as food these days. It is only used as fodder for pigs. As such the number of varieties has decreased.

Among both the groups, the traditional crops that have lost their importance as food have now given way to various vegetables, spices and fruit crops. These have become important accompaniments to rice and other major food, resulting in an increase in the number of species and varieties of such crops. This can be seen in the home gardens and swidden plots maintained by women.

communities influence the systems of, and are reflected in, the agro-biodiversity management of the communities.

By virtue of their gender roles, both Naga and Lepcha women have played and continue to play a key role in the management and conservation of agro-biodiversity as indigenous breeders, 
knowledge managers and holders, and seed distributers (Inhetveen 1998). This study shows that women's distinct roles in agricultural labour and their authority over the three levels (agroecosystem, species and gene) based on their gender, places women in a position of managing and conserving agro-biodiversity more directly.

Traditional systems of seed management, food habits, food preferences and preparation methods, the ritual and socio-cultural significance attached to certain crops, are all factors on which crop diversity depends. In such a system, women are the principal custodians of agro-biodiversity. However, what appear as pure conservation strategies are culturally embedded activities, making sense for the actors only from a livelihood perspective (Padmanabhan 2005). In addition, as the market economy views all transactions in the non-market realm as of no value, women's work and knowledge are not seen as conservation strategies in any way.

As incidences of poverty and low household incomes are fairly easy to measure in today's world, poverty has become the standard yardstick for development. While measuring the success of development in the eastern Himalaya and the northeastern region, perhaps the indigenous native communities of the region rank lowest and rarest of all. As the true ends of development are not incomes but freedom to choose a way of life (Sen 1999) and ability to adapt in the ever-changing landscape, the livelihood practices of these peoples are adaptive by enduring external changes that influence their livelihood and society. This inclusive societal arrangement had always benefited them as agrarian forest dwellers. However, such a lifestyle has also isolated them, so they remain marginalised from the mainstream development. At the same time, the increasing influences of both global and regional market economies, land tenure issues, and a rapidly increasing population have combined to create and intensify socio-ecological as well as political conflicts. The overall spin-off of these occurrences is that major parts of this region are undergoing movements for cultural and political rights and recognition resulting in clashes not only with the government(s) in power, but in many instances among the various communities themselves. In this surcharged clash of identities in the region, women's contributions, their equitable 
recognition and economic reward are all but diluted despite these being key issues in the sustainable management of agrobiodiversity. Bearing in mind the changing times and history of the region and its peoples, it is difficult to predict how gender relations, land-related stewardship and sustainable agro-biodiversity conservation will play out.

\section{Notes}

* This essay draws upon the findings from the Project 'Gender, Ethnicity and Agro-biodiversity Management in the Eastern Himalayas', funded by the International Development Research Centre (IDRC), Canada. The research team included Chanda Gurung Goodrich, Sion Lepcha, Chozule Kiki, and Aneugla Aier.

Previous and different versions of this essay have appeared in $\mathrm{Habi}$ tat Himalaya - A Resources Himalaya Factfile, 8(1), 2001; Agrobiodiversity Conservation and the Role of Rural Women, Expert Consultation Report, 2002, FAO, Regional Office for Asia and the Pacific, Bangkok, Thailand; International Potato Center-Users' Perspectives with Agriculture Research and Development (CIP-UPWARD), Los Banos, Laguna, Philippines; SEAMEO South-east Asia Regional Center for Graduate Study and Research in Agriculture (SEAMEO-SEARCA) RAP Publication 2002/07; Mountain Agriculture in the Hindu Kush-Himalayan Region, 2003, Tang Ya and Pradeep M. Tulachan (eds), Proceedings of an International Symposium held 21-24 May, 2001 in Kathmandu, Nepal.,ICIMOD, Kathmandu, Nepal.

\section{References}

Agarwal, B. 2000. 'Conceptualising Environmental Collective Action: Why Gender Matters', Cambridge Journal of Economics, 24(3): 283-310.

Gorer, Geoffery. 1938 (1987). The Lepchas of Sikkim. Delhi: Gian Publishing House.

Gurung, Chanda and Nawraj Gurung. 2006. 'The Social and Gendered Nature of Ginger Production and Commercialization: A Case Study of the Rai, Lepcha and Brahmin-Chhetri in Sikkim and Kalimpong, West Bengal, India', in R. Vernooy (ed.), Social and Gender Analysis in Natural Resource Management. Learning Studies and Lessons from Asia. New Delhi: Sage Publications; International Development Research Centre, Canada; China Agriculture Press, Beijing, China, pp. 37-64. 
Gurung, Jeannette D. (ed.). 1999. Searching for Women's Voices in the Hindukush-Himalayas. Kathmandu:International Centre for Integrated Mountain Development.

Howard, P. L. 2003. Women and Plants: Gender Relations in Biodiversity Management \& Conservation.London and New York: Zed Press.

Howard-Borjas, P. 2001. 'Women in the Plant World: The Significance of Women and Gender Bias for Botany and Biological Diversity', Inaugural Address, University of Wageningen, Wageningen.

Inhetveen, H. 1998. 'Women Pioneers in Farming: Gendered History of Agricultural Progress', Sociologia Ruralis, 38(3): 265-84.

Lambrou, Yianna and Regina Laub. 2006. 'Gender, Local Knowledge, and Lesson Learnt in Documenting and Conserving Agrobiodiversity', Research paper No. 2006/69), United Nations University, UNU-WIDER.

Momsen, J. H. 2004. Gender and Development. London and New York: Routledge.

Myers, N. 1988. 'Threatened Biotas: Hot Spots in Tropical Forests', The Environmentalist, 8(3): 187-208.

Nakro, Vengota and Chozule Kikhi. 2006. 'Strengthening Market Linkages for Women Vegetable Vendors', in R. Vernooy (ed.), Social and Gender Analysis in Natural Resource Management. Learning Studies and Lessons from Asia. New Delhi: Sage Publications; International Development Research Centre, Canada; China Agriculture Press, Beijing, China, pp. 65-94.

Oakley, Emily and Janet Henshall Momsen. 2005. 'Gender and Agrobiodiversity: A Case Study from Bangladesh', The Geographical Journal, 177(3): 195-208.

Padmanabhan, Martina Aruna. 2005. 'Institutional Innovations towards Gender Equity in Agrobiodiversity Management - Collective Action in Kerela, South India'. CAPRi Working Paper \# 9. International Food Policy Research Institute (IFPRI).

Rocheleau, D., E. Wangari and B. Thomas-Slayter. 1996. Feminist Political Ecology: Global Issues and Local Experience. London and New York: Routledge.

Sachs, C. E., K. Gajural and M. Bianco. 1997. 'Gender, Seeds and Biodiversity', in C. E. Sachs (ed.), Women Working in the Environment. London and Washington DC: Taylor \& Francis.

Secretariat of the Convention on Biological Diversity. 2001. Assessment and Management of Alien Species that Threaten Ecosystems, Habitats and Species. CBD Technical Series, No. 1, Montreal, Canada.

Sen, A. 1999 Development as Freedom. London: Oxford University Press. Siiger, Halfden. 1967. The Lepchas - Culture and Religion of a Himalayan 
People: Part I. Copenhagen: The National Museum of Denmark. Zimmerer, K. S. 1996. Changing Fortunes: Biodiversity and Peasant Livelihood in the Peruvian Andes. Berkeley: University of California Press.

Zwarteveen, Margreet. 2008. 'Seeing Women and Questioning Gender in Water Management'. Paper submitted for the panel 'Engendering Water Governance in South Asia: Re-thinking Policy and Practice', International Conference on Water Resources Policy in South Asia (SaciWaters, 18-20 December 2008, Colombo, Sri Lanka). 